\title{
PENGARUH BRAND IMAGE, BRAND TURST, EWOM TERHADAP PURCHASE INTENTION PADA PRODUK H\&M PADA MASA PANDEMI COVID-19
}

\author{
Hendri dan Herlina Budiono \\ Program Studi Manajemen Fakultas Ekonomi Universitas Tarumanagara, Jakarta \\ Hendri.115160390@stu.untar.ac.id
}

\begin{abstract}
Fashion brands are increasingly being caused by the needs of society and technological developments in creating new products that are very practical and creative, especially during a pandemic more and more are shopping online. The purpose of this study is to examine whether the effect of brand image, brand trust, and EWOM are positive predictor of purchase intention for H\&M product during the covid-19 in Jakarta. This study uses 100 samples selected using convenience sampling techniques, where the selected sample is consumers in Jakarta who have bought or tried H\&M products. The instruments to collect the data was by questionnaire and distributed through social media platforms, such as Whatsapp, Line and Instagram. Data were analyzed using PLS-SEM. The results of this study indicate that brand image, brand trust and EWOM is a positive predictor of purchase intention.
\end{abstract}

Keywords: Brand Image, Brand Trust, EWOM, Purchase Intention.

Abstrak: Merek fashion semakin banyak disebabkan karena kebutuhan masyarakat dan perkembangan teknologi dalam menciptakan produk-produk baru yang sangat praktis dan kreatif, khususnya pada masa pandemi semakin banyak yang belanja melalui online. Tujuan penelitian ini adalah untuk menguji apakah pengaruh citra merek, kepercayaan merek dan EWOM merupakan prediktor positif untuk niat membeli pada produk H\&M pada masa pandemi covid-19 di Jakarta. Penelitian ini menggunakan 100 sampel yang dipilih dengan menggunakan teknik convenience sampling, dimana sampel yang dipilih adalah konsumen di Jakarta yang pernah membeli atau mencoba produk H\&M. Teknik pengambilan data dilakukan dengan menggunakan kuesioner dan disebar melalui media sosial berupa Whatsapp, Line dan Instagram. Data dianalisis dengan menggunakan PLS-SEM. Hasil penelitian ini menunjukkan bahwa persepsi citra merek, kepercayaan merek dan EWOM merupakan prediktor positif untuk niat membeli.

Kata Kunci: Citra Merek, Kepercayaan Merek, EWOM, Niat Membeli.

\section{LATAR BELAKANG}

Pada zaman saat ini mudah sekali kita mendapatkan informasi-informasi salah satunya yaitu lewat media sosial mengenai informasi tentang fashion. Fashion dan style merupakan hal yang cukup penting bagi seseorang karena lewat fashion akan menciptakan kesan-kesan yang baik atau buruk bagi orang-orang. Bahkan berdasarkan artikel dalam kompas.com, salah satu tips untuk meningkatkan kepercayaan diri seseorang yaitu melalui berpakaian yang rapi yaitu memilih pakaian dengan style fashion yang cocok.

Perkembangan teknologi dalam menciptakan produk-produk baru yang sangat praktis dan kreatif. Berdasarkan artikel online dalam Akurat.co persaingan industri fashion saat ini di 
Indonesia sangat ketat dikarenakan fashion sudah mengarahkan penjualannya melalui media sosial, situs web ataupun yang lainnya. Apalagi pada masa pandemi seperti ini dapat kita ketahui bahwa semakin banyak yang belanja melalui online.

Purchase Intention sangat penting dalam penelitian ini, Reza \& Samiei, Neda (2012) menunjukkan bahwa definisi Purchase Intention mewakili kebiasaan konsumen, yaitu ada di pasar dan merupakan keunggulan kompetitif perusahaan. Kita mengetahui bahwa Purchase Intention hampir terjadi pada setiap hari terutama di pusat perbelanjaan yang terkenal dan berbagai destinasi-destinasi dan salah satu hal dapat membuat konsumen mengalami Purchase Intention yaitu Brand Image.

Dapat kita ketahui bahwa H\&M telah menciptakan Brand Image yang kuat khususnya di Indonesia. Konsumen tidak hanya mencari produk, harga, promosi dan tempat yang sesuai tetapi faktor lain seperti persepsi Brand Image dan kualitas. (Mohd Ali, K A, Abd Hafiz, 2018).

Semua komponen dalam stimuli pemasaran seperti produk, harga, promosi dan tempat ada pengaruh yang signifikan terhadap persepsi Brand Image. (Mohd Ali, K A, Abd Hafiz, 2018). Ini menandakan bahwa Brand Image memberikan dampak yang besar kepada konsumen. Semakin konsumen membeli produk akan memberi dampak terhadap Brand Image yang baik terhadap perusahaan dikarenakan konsumen akan merasa nyaman dan kepercayaan konsumen terhadap Brand akan meningkat.

Brand Trust adalah fondasi bisnis. Membangun kepercayaan dalam hubungan jangka panjang dengan pelanggan merupakan faktor penting untuk menciptakan loyalitas pelanggan. Keyakinan ini tidak sekadar menjadi diakui oleh pihak / mitra bisnis lain tetapi harus dibangun sejak awal dan bisa dibuktikan (Rosmayani \& Mardhatillah, 2020). Oleh sebab itu Brand Trust menjadi salah satu hal yang tidak dapat dihilangkan ketika perusahaan ingin membangun hubungan dengan konsumen. Ketika fondasi Brand Trust sudah kuat maka konsumen akan memberitakan informasi-informasi kepada orang-orang di sekeliling dan menciptakan Brand Image yang baik.

E-WOM adalah WOM yang diistilahkan dalam konteks Internet (Soares et al., 2012). Hampir setiap dari kita mempunyai media sosial dengan konsumen memposting rekomendasi dan opini tentang suatu produk atau layanan di halaman profil atau media sosial mereka, dengan demikian akan mempengaruhi orang-orang yang menggunakan media sosial (Kudeshia \& Kumar, 2017). Dengan kata lain semakin banyak konsumen yang merekomendasi produk ataupun merek suatu produk maka akan membawa keuntungan yang besar bagi perusahaaan.

Semua variabel memiliki keterkaitan antara satu sama lainnya. Pada era digitalisasi seperti ini media sosial menjadi sebuah media untuk bersosialisasi dan berinteraksi satu sama lain dan dilakukan secara online, kemajuan teknologi informasi menyebabkan semakin banyak konsumen yang mencari informasi yang dibutuhkan terhadap suatu produk ataupun merek sebelum mereka melakukan pembelian ulang. Semakin konsumen merekomendasi produk atau merek suatu produk di media sosial maka akan membawa keuntungan yang besar bagi perusahaan. Dengan semakin banyaknya ulasan-ulasan yang positif maka mampu menciptakan Brand Image yang baik bagi produk ataupun merek H\&M dihadapan konsumen dan ketika konsumen memakai produk $\mathrm{H} \& \mathrm{M}$, produk tersebut akan meningkatkan rasa kepercayaan diri konsumen dikarenakan konsumen percaya terhadap produk ataupun merek $\mathrm{H} \& \mathrm{M}$ hal ini dikarenakan adanya rasa kepercayaan yang dibangun antara perusahaan dan konsumen.

Berdasarkan penjabaran tersebut, peneliti merumuskan masalah penelitian sebagai berikut: "Apakah Brand Image, Brand Trust, EWOM merupakan prediktor positif terhadap Purchase Intention produk H\&M di Jakarta?" 


\section{KAJIAN TEORI}

Purchase Intention. Niat membeli mengacu pada kemungkinan bahwa konsumen berencana atau bersedia membeli merek suatu barang tertentu di masa depan Huang et al. (2011). Laksmi dan Oktafani (2016) mengatakan bahwa Puchase Intention merupakan keinginan seseorang konsumen terhadap pemenuhan kebutuhan dan keinginan yang tersembunyi dalam benak konsumen. Firona dan Iskandar (2018) juga mengatakan bahwa perasaan dan emosi yang terbentuk karena adanya rangsangan setelah terdapat pengalaman atas suatu produk, dimana pengalaman tersebut memberi rasa percaya dan kepuasan yang mendorong minat seseorang untuk membeli produk tersebut. Selanjutnya Spears dan Singh (2004) mengatakan bahwa: "Purchase Intention is defined as an individual's conscious plan to make an effort to purchase a brand". Dapat diartikan bahwa Purchase Intention didefiniskan sebagai kesadaran individu dalam rencana untuk melakukan upaya untuk membeli sebuah merek. Dengan demikian, dapat disimpulkan bahwa Purchase Intention adalah sebuah keinginan atau rencana konsumen yang terselubung dalam supaya untuk membeli sebuah produk atau merek.

Brand Image. Farzin dan Fattahi (2018) mendefinisikan Brand Image dapat mencakup artibut dan manfaat yang terkait dengan suatu merek yang membuat merek tersebut menjadi istimewa dan berbeda dari pesaingnya. Keller (2013: 768) Brand Image ialah persepsi konsumen tentang suatu merek yang dapat dicerminkan melalui asosiasi merek yang ada didalam ingatan konsumen. Kotler dan Keller (2016: 330) menjelaskan bahwa Brand Image adalah: "the extrinsic properties of the product or service, including the ways in which the brand attempts to meet customers' psychological or social needs. " Sifat ekstrinsik dari suatu produk atau jasa, termasuk cara dari suatu merek untuk memenuhi kebutuhan psikologis dan sosial konsumen. Berdasarkan defisini tersebut, dapat kita simpulkan bahwa Brand Image adalah persepsi konsumen tentang suatu merek, persepsi tersebut akan membuat suatu merek menjadi istimewa serta berbeda dibandingkan merek lain.

Brand Trust. Ennew dan Sekhon (2007) mengatakan bahwa kepercayaan sebagai kesediaan individu untuk menerima kerentanan atas dasar positif ekspektasi tentang niat atau perilaku orang lain dalam situasi yang ditandai saling ketergantungan dan resiko. Oleh karena itu, kepercayaan konsumen dapat diartikan sebagai fungsi tingkat risiko yang terlibat dalam situasi tersebut dan pada dasarnya hanya diperlukan di situasi yang tidak pasti. Nadhifa (2011) mengatakan bahwa Brand Trust merupakan fondasi dari bisnis. Suatu transaksi bisnis antara dua pihak atau lebih akan terjadi apabila masing-masing pihak saling mempercayai. Brand Trust ini tidak begitu saja dapat diakui oleh pihak lain / mitra bisnis, melainkan harus mulai dibagun dari awal dan dapat dibuktikan. Gefen dan Straub (2004) mendefinisikan Brand Trust sebagai: "Trust is an interpersonal determinant of behavior that deals with beliefs about the integrity, benevolence, ability, and predictability of other people." Yang berarti kepercayaan adalah penentu perilaku interpersonal yang berhubungan dengan keyakinan tentang integritas, kebajikan, kemampuan, dan prediktabilitas seseorang.

E-WOM. Hennig-Thurau et al. (2004: 39) mengatakan bahwa E-WOM adalah: "as any positive or negative statement made by potential, actual, or former customers about a product or company, which is made available to a multitude of people and institutions via the Internet." E-WOM merupakan sebagai segala pernyataan positif maupun negatif terhadap suatu perusahaan atau produk yang dibuat di media internet oleh pembeli potensial, aktual, maupun yang sudah membeli. Cheung et al. (2008) "E-WOM can also be considered as the 
extension of traditional interpersonal communication into the new generation of cyberspace". Di mana dapat diartikan bahwa E-WOM adalah sambungan dari komunikasi antar manusia secara tradisional menjadi generasi baru dalam dunia maya. Litvin et al. (2008) mengatakan bahwa "E-WOM can be defined as all informal communications directed at consumers through Internet-based technology related to the usage or characteristics of particular goods and services, or their sellers". Dimana dapat diartikan sebagai semua komunikasi informal yang ditujukan kepada konsumen melalui teknologi berbasis internet yang berhubungan dengan penggunaan atau karakteristik dari barang dan jasa tertentu, atau penjualnya.

Kaitan antara Brand Image dan Purchase Intention. Jalilvand dan Samiei (2012) menjelaskan bahwa dalam memperbaiki sebuah Brand Image dapat dilakukan dengan meningkatkan berbagai produk, meningkatkan kualitas produk, menawarkan produk dalam harga yang layak, dan menyediakan layanan purna jual. Perbaikan seperti ini secara langsung dapat meningkatkan Purchase Intention. Farzin dan Fattahi (2018) menjelaskan bahwa Brand Image dapat mempengaruhi Purchase Intention secara positif. Ketika suatu produk dijual oleh perusahaan yang mempunyai Brand Image positif, Image positif tersebut mendorong Purchase Intention konsumen akan produk. Kemudian penelitian yang dilakukan oleh Ahmad et al. (2020) menjelaskan bahwa dikarenakan Brand Image berpengaruh positif terhadap Purchase Intention. Oleh sebab itu, untuk dapat lebih menjaga kualitas merek, mutu merek dan tetap mengutamakan manfaat produk tersebut agar supaya menimbulkan rasa percaya diri konsumen untuk memiliki minat dalam membeli suatu produk.Rifai et al. (2016) menjelaskan bahwa citra positif yang terdapat pada suatu merek menjadikan konsumen tidak ragu untuk memiliki Purchase Intention. Hal tersebut berarti jika perluasan merek yang sudah dikenal baik konsumen meningkat, Brand Image akan semakin membaik sehingga akan memberikan pengaruh terhadap Puchase Intention.

\section{H1 : Brand Image dapat memprediksi secara positif Purchase Intention H\&M di Jakarta}

Kaitan antara Brand Trust dan Purchase Intention. Lien et al. (2015) menjelaskan bahwa dalam menentukan beberapa faktor pendorong dari Purchase Intention selain dari harga produk atau layanan, nilai yang memuaskan, Brand Trust juga menjadi salah satu faktor dalam mendorong konsumen untuk melakukan Purchase Intention. H.Kim et al. (2012) menjelaskan bahwa: "a trust in the brand will make consumers have greater intention to purchase the product/service." Kepercayaan pada merek akan membuat konsumen memiliki niat yang lebih besar untuk membeli produk / jasa. D.J.Kim (2008) juga menyatakan bahwa Brand Trust berpengaruh signifikan terhadap Purchase Intention. Ketika Brand Trust meningkat, maka konsumen cenderung melihat risiko yang lebih kecil dari pada jika Brand Trust tidak ada, efek kepercayaan akan dimediasi oleh risiko pada Purchase intention.

\section{H2 : Brand Trust dapat memprediksi secara positif Purchase Intention H\&M di Jakarta}

Kaitan antara $\boldsymbol{E}$-WOM dan Purchase Intention. Jalilvand dan Samiei (2012) menjelaskan bahwa E-WOM memiliki keterikatan yang positif dan kuat terhadap Purchase Intention. EWOM sangat berperan penting dalam mempengaruhi Purchase Intention konsumen. Dengan adanya kemajuan teknologi yang sangat cepat dan praktis, untuk mencari suatu informasi tentang suatu produk atau perusahaan konsumen sangat mengandalkan internet. Farzin dan Fattahi (2018) mengatakan bahwa ketika konsumen mempunyai niat untuk membeli suatu produk, terlebih dahulu konsumen akan mempelajari hal-hal berkaitan dengan produk di situs jejaring sosial yang diakses melalui smartphone. Penelitian ini menunjukkan bahwa adanya 
pengaruh positif antara E-WOM mempengaruhi Purchase Intention. Gevi Tonida Resky (2016) menjelaskan bahwa $E$-WOM positif juga dapat mempersuasi pelanggan potensial dan mempengaruhi Purchase Intention pelanggan terhadap suatu review produk ataupun yang di rekomendasikan pelanggan lain. Widjaja (2016) juga menjelaskan bahwa penggunaan telepon genggam pintar yang mendukung konsumen untuk aktif menggunakan internet dan media sosial membuat aktivitas mencari informasi mengenai produk meningkat sebelum pembelian pula seperti misalnya melihat ulasan pada situs, forum, blog, atau media sosial itu sendiri dengan melihat apa yang di-post atau reply oleh teman.

Begitu juga Adrian Gae Lomi (2016) menjelaskan bahwa E-WOM yang dilakukan antar konsumen saling mempengaruhi dalam memunculkan Purchase Intention. Pengalaman konsumen sebelumnya menjadi informasi penting dan mempengaruhi pandangan pada konsumen lain yang akan melakukan pembelian.

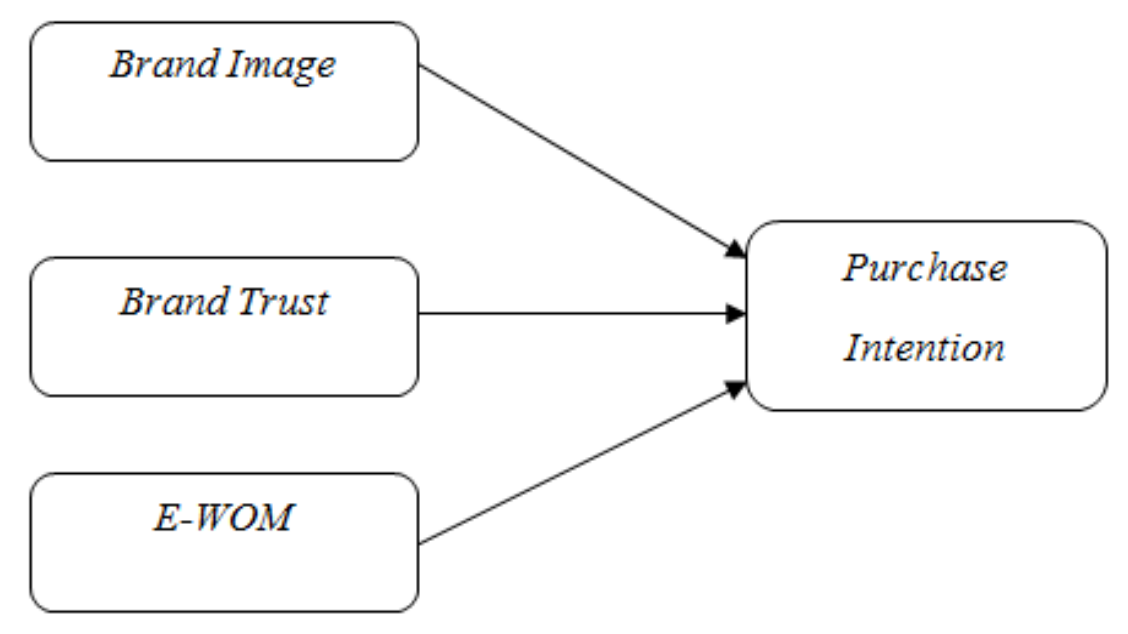

H3 : E-WOM dapat memprediksi secara positif Purchase Intention H\&M di Jakarta

Berdasarkan kaitan-kaitan antar variabel di atas, maka model penelitian yang dirumuskan adalah sebagai berikut :

Gambar 1. Model Penelitian

\section{METODE}

Desain penelitian ini menggunakan desain penelitian deskriptif kuantitatif. Penelitian descriptive adalah penelitian terstruktur yang bertujuan untuk mendeskripsikan karakteristik suatu pasar atau fungsi Maholtra et al. (2017:73). Penelitian ini dilakukan dengan menyebarkan kuesioner melalui google form kepada konsumen yang telah mencoba produk H\&M. Penelitian ini melibatkan 100 responden untuk untuk mengetahui penggaruh dari variabel independen (brand image, brand trust, EWOM) terhadap variabel dependen yaitu purchase intention. Metode yang digunakan untuk penelitian adalah metode cross sectional. Penelitian ini diuji dengan menggunakan teknik analisis regresi ganda dengan pengujian validitas menggunakan aplikasi Smart PLS 3. Pengukuran semua indikator dilakukan menggunakan skala likert 1-5. Malhotra et al. (2017:349) menjelaskan bahwa skala likert adalah sebuah skala pengukuran dengan lima kategori responsive dari "strongly disagree" to "strongly agree", dimana mensyaratkan responden untuk menunjukkan tingkat persetujuan atau ketidaksetujuan dengan masing-masing dari serangkaian pernyataan yang terkait dengan objek stimulus. 
Tabel 1

Variabel Data Pengukuran

\begin{tabular}{|c|c|c|}
\hline Variabel & Jumlah Item & Sumber \\
\hline $\begin{array}{l}\text { Variabel Independen: } \\
\text { 1. Brand Image } \\
\text { 2. Brand Trust } \\
\text { 3. EWOM }\end{array}$ & $\begin{array}{l}4 \\
5 \\
4\end{array}$ & $\begin{array}{l}\text { Farzin \& Fatthahi (2018); Dan J. } \\
\text { Kim et al. (2008); Anggitasari \& } \\
\text { Wijaya 2016); Farzin \& Fatthahi } \\
\text { (2018);Jalilvand \& Samiei } \\
\text { (2012); Prasad et al. (2019); }\end{array}$ \\
\hline $\begin{array}{l}\text { Variabel Dependen: } \\
\text { Purchase Intention }\end{array}$ & 5 & \\
\hline
\end{tabular}

Sumber : Olahan Data Kuesioner

\section{Hasil Uji Statistik}

Hasil analisis data secara singkat tertera pada Tabel 2 berikut ini

Tabel 2. Hasil Pengujian Path Coefficients dengan Bootstrapping

\begin{tabular}{|l|c|c|c|}
\hline \multicolumn{1}{|c|}{ Variabel } & $\begin{array}{c}\text { Path } \\
\text { Coefficients }\end{array}$ & T-Statistics & P-Values \\
\hline Brand Image >> Purchase Intention & 0,455 & 3,867 & 0,000 \\
\hline Brand Trust $>>$ Purchase Intention & 0,178 & 1,510 & 0,132 \\
\hline EWOM >> Purchase Intention & 0,235 & 2,585 & 0,010 \\
\hline
\end{tabular}

Sumber : Olahan Data Smart PLS

Catatan : Mendekati nilai +1 pada path coefficient mempresentasi bahwa hubungan antar variabel bersifat strong positive relationship, nilai $p$-value nilainya harus dibawah $\alpha=0,05$ (valid), \%),nilai signifikansi weight T-statistics $>1,96$.

\section{PEMBAHASAN}

Pada hasil pengujian hipotesis pertama $\left(\mathrm{H}_{1}\right)$ menunjukkan bahwa Brand Image merupakan prediktor positif untuk Purchase Intention. Sehingga dapat disimpulkan bahwa hipotesis ini didukung dan sejalan dengan penelitian yang dilakukan oleh Rifai et al. (2016) Setiawaty (2017) dan Jalilvand \& Samiei (2012). Hasil penelitian ini menemukan bahwa adanya Brand Image yang positif akan membangun konsumen dalam meningkatkan Purchase Intention. Sebuah Brand Image yang baik dapat memberi suatu kesan kepada konsumen. Semakin terkenal Brand Image maka semakin tinggi Purchase Intention konsumen.

Pada hasil pengujian hipotesis kedua $\left(\mathrm{H}_{2}\right)$ menunjukkan bahwa Brand Trust merupakan prediktor positif untuk Purchase Intention. Sehingga dapat disimpulkan bahwa hipotesis ini didukung dan sejalan dengan penelitian yang dilakukan oleh Lien et al. (2015), Kim et al. (2012) dan Kooli et al. (2014) yang menyatakan bahwa Brand Trust mempunyai pengaruh positif terhadap Purchase Intention.

Pada hasil pengujian hipotesis ketiga $\left(\mathrm{H}_{3}\right)$ menunjukkan bahwa EWOM merupakan prediktor positif untuk Purchase Intention. Hasil ini didukung oleh Jalilvand \& Samiei 
(2012), Adrian Gae Lomi (2016) dan Widjaja (2016). Sehingga dapat disimpulkan bahwa EWOM berpengaruh terhadap Purchase Intention dan EWOM yang terjadi lebih banyak yang bersifat positif dibandingkan dengan komunikasi yang bersifat negatif yang disebarkan netizen melalui media sosial.

\section{PENUTUP}

Berdasarkan hasil penelitian ini bagi perusahaan sebaiknya perlu memperhatikan Brand Image. Hal ini karena dengan Brand Image dapat memberitahukan kepada konsumen bahwa H\&M adalah Brand yang baik. Hal ini penting dilakukan mengingat bahwa variabel yang sangat mempengaruhi penelitian ini adalah Brand Image. Dengan adanya cara ini, perusahaan H\&M akan tetap menjaga bahkan meningkatkan Brand Image dari perusahaan yang lebih baik kepada konsumen. Penggunaan media sosial perlu terus ditingkatkan dengan berbagai inovasi agar meningkatkan Purchase Intention konsumen di Jakarta. Apalagi di masa pandemi sekarang, media sosial sangat popular buat konsumen dalam mencari informasi mengenai produk yang ingin dibeli. Oleh karena itu, H\&M perlu memanfaatkan media sosial dengan baik khususnya Instagram. Saran yang bisa dilaksanakan supaya jawaban dari hasil kuesioner dari setiap variabel yang rendah dapat mengalami peningkatan, H\&M harus meningkatkan rasa kepercayaan konsumen terhadap H\&M yaitu dapat melalui memberi promo, potongan harga, bahkan dapat juga memberi give away berupa voucher supaya konsumen dapat melakukan pembelian kembali pada saat mereka membutuhkan. Selain itu, H\&M juga dapat membangun hubungan lebih bersama konsumen dalam memberikan souvenir didalam kegiatan-kegiatan, acara-acara, atau hari besar contohnya hari natal, hari idulfitri, hari paskah, hari imlek dan hari-hari besar yang lainnya termasuk acara-acara yang lainnya sehingga rasa kepercayaan antara konsumen dan perusahaan akan meningkat tentunya H\&M juga harus berkomitmen dan menepati janji dalam membangun hubungan bersama konsumen. H\&M dapat juga melakukan inovasi didalam aplikasi online yang berupa memberi ulasan-ulasan, penilaian produk supaya konsumen dapat mengumpulkan informasiinformasi dan dapat menciptakan Image yang baik dihadapan konsumen, semakin banyak yang memberi ulasan positif maka Brand Image yang diciptakan dihadapan konsumen adalah baik.

\section{DAFTAR PUSTAKA}

Anggitasari, A. M., \& Wijaya, T. (2016). Pengaruh Ewom Terhadap Brand Image Dan Brand Trust, Serta Dampaknya Pada Minat Beli Produk Smartphone Iphone (Studi Pada Masyarakat Di Yogyakarta). Jurnal Manajemen Bisnis Indonesia, 5(3), 266-275.

Adrian Gae Lomi, J. L. . B. (2016). Pengaruh eWOM (. Journal Of Management, 2(1), 29-58. Ahmad, M., Tumbel, T. M., \& Kalangi, J. A. (2020). Pengaruh Citra Merek Terhadap Minat Beli Produk Oriflame Di Kota Manado. 10(1), 25-31. https://doi.org/10.1017/CBO9781107415324.004

Ennew, C., \& Sekhon, H. (2007). Measuring trust in financial services: The Trust Index. Consumer Policy Review, 17(2), 62.

Farzin, M., \& Fattahi, M. (2018a). eWOM through social networking sites and impact on purchase intention and brand image in Iran. Journal of Advances in Management Research, 15(2), 161-183.

Farzin, M., \& Fattahi, M. (2018b). eWOM through social networking sites and impact on purchase intention and brand image in Iran. Analisis Pengaruh Electronic Word Of Mouth (e-WOM) Terhadap Minat Beli Konsumen Pada Produk Tas di Instagram 
RGFASHION STORE, 15(2), 161-183. https://doi.org/10.1108/JAMR-05-2017-0062

Firona, W., \& Iskandar, D. A. (2018). Pengaruh Direct Selling Dan Media Sosial Melalui Facebook Terhadap Minat Beli Konsumen Pada Rokok Sin Herbal. Jurnal Riset Manajemen Dan Bisnis (JRMB) Fakultas Ekonomi UNIAT, 3, 213-222.

Gefen, D., \& Straub, D. W. (2004). Consumer trust in B2C e-Commerce and the importance of social presence: Experiments in e-Products and e-Services. Omega, 32(6), 407-424. https://doi.org/10.1016/j.omega.2004.01.006

Hennig-Thurau, T., Gwinner, K. P., Walsh, G., \& Gremler, D. D. (2004). Electronic word-ofmouth via consumer-opinion platforms: What motivates consumers to articulate themselves on the Internet? Journal of Interactive Marketing, 18(1), 38-52.

Huang, Y. C., Wu, Y. C. J., Wang, Y. C., \& Boulanger, N. C. (2011). Decision making in online auctions. Management Decision, 49(5), 784-800.

Jalilvand, M. R., \& Samiei, N. (2012). The effect of electronic word of mouth on brand image and purchase intention: An empirical study in the automobile industry in Iran. Marketing Intelligence and Planning, 30(4), 460-476.

Keller, Kevin L, (2013). Strategic Brand Management; Building, Measuring, and Managing Brand Equity. 4th, Pearson Education, Inc.

Kim, D. J., Ferrin, D. L., \& Rao, H. R. (2008). A trust-based consumer decision-making model in electronic commerce: The role of trust, perceived risk, and their antecedents. Decision Support Systems, 44(2), 544-564.

Kim, H., Xu, Y., \& Gupta, S. (2012). Electronic Commerce Research and Applications Which is more important in Internet shopping, perceived price or trust? Electronic Commerce Research and Applications, 11(3), 241-252.

Kooli, K., Mansour, K. Ben, \& Utama, R. (2014). Determinants of online trust and their impact on online purchase intention. International Journal of Technology Marketing, 9(3), 305.

Kotler, P., and Keller, K.L. (2016). Marketing Management. 15th Edition, Pearson Education,Inc.

Kudeshia, C., \& Kumar, A. (2017). Social eWOM: does it affect the brand attitude and purchase intention of brands? Management Research Review, 40(3), 310-330.

Laksmi, A. A., \& Oktafani, F. (2016). Pengaruh Electonic Word Of Mouth (eWOM) Terhadap Minat Beli Followers Instagram Pada Warunk Upnormal. Jurnal Computech \& Bisnis, 10(2), 78-88. www.dailysocial.id

Lien, C. H., Wen, M. J., Huang, L. C., \& Wu, K. L. (2015). Online hotel booking: The effects of brand image, price, trust and value on purchase intentions. Asia Pacific Management Review, 20(4), 210-218.

Litvin, S. W., Goldsmith, R. E., \& Pan, B. (2008). Electronic word-of-mouth in hospitality and tourism management. Tourism Management, 29(3), 458-468.

Malhotra, N., Nunan, D., \& Birks, D. (2017). Marketing Research: An Applied Approach. (5 ed.) Pearson.

Mohd Ali, K A, Abd Hafiz, K. (2018). Testing the Black Box'S Model on Cosmetic Products: a Psychological Perspective. J Fundam Appl Sci, 10(1S), 995-1007.

Nadhifa, K. (2011). Pengaruh Dimensi Trust Terhadap Partipasi Pelanggan E-Commerce di Kabupaten Jember.

Resky, G.T., \& Hendrawan, D. (2016). Analais Pengaruh Electronic Word Of Mouth (eWOM) Terhadap Minat Beli Konsumen Pada Produk Tas di Instagram RGFASHION STORE. Analasis Pengaruh Electronic Word Of Mouth (e-WOM) Terhadap Minat Beli Konsumen Pada Produk Tas di Instagram RGFASHION STORE, 11(3), 55.

Reza, M., \& Samiei, Neda, J. (2012). The effect of electronic word of mouth on brand image 
and purchase intention: An empirical study in the automobile industry in Iran. Marketing Intelligence and Planning, 30(4), 460-476.

Rifai, H., Kumadji, S., \& Yulianto, E. (2016). Pengaruh Perluasan Merek Terhadap Citra Merek dan Dampaknya Terhadap Minat Beli (Survei pada Pengguna Produk Induk Merek Lifebuoy pada Mahasiswa S1 dan D3 Universitas Brawijaya ). Jurnal Administrasi Bisnis S1 Universitas Brawijaya, 35(1), 120-126.

Rosmayani, \& Mardhatillah, A. (2020). Model of intention to behave in online product purchase for Muslim fashion in Pekanbaru, Indonesia. Journal of Islamic Marketing.

Setiawaty, N. (2017). Pengaruh Iklan, Citra Merek, Dan Kepercayaan Merek Terhadap Minat Beli Konsumen Smartphone Samsung Galaxy Series (Studi Kasus Mahasiswa/I Universitas Gunadarma, Depok). Jurnal Ilmiah Ekonomi Bisnis, 22(1), 96601.

Soares, A. M., Pinho, J. C., \& Nobre, H. (2012). From Social to Marketing Interactions: The Role of Social Networks. Journal of Transnational Management, 17(1), 45-62.

Spears, N., \& Singh, S. N. (2004). Measuring attitude toward the brand and purchase intentions. Journal of Current Issues and Research in Advertising, 26(2), 53-66. https://doi.org/10.1080/10641734.2004.10505164

Widjaja, A. T. (2016). Pengaruh Word of Mouth Dan Electronic Word of Mouth. Bisnis Dan Manajemen, 53, 241-253.

https://lifestyle.kompas.com/read/2015/02/20/1300007/12.Cara.Mudah.Meningkatkan.Keperc ayaan.Diri

https://akurat.co/gayahidup/id-833973-read-persaingan-industri-fashion-makin-ketatpenjualan-online-jadi-lini-terdepan 